\title{
Laboratory Exercise on the Segregation of Flower Color and Related Genes Using Velvet Flower (Salpiglossis sinuata Ruiz et Pavon)
}

\author{
Chiwon W. Lee
}

AdDITIONAL INDEX WORDS. flower color inheritance, cleistogamy, pollination, genetic segregation

Summary. Velvet flower (Salpiglosissinuata, Solanaceae) can be used as an excellent demonstration plant for horticultural crop breeding classes. Salpiglossis produces large trumpetlike flowers exhibiting an assortment of corolla colors and pigmentation patterns. The pistil is large ( 3 to $4 \mathrm{~cm}$ or 1.2 to 1.6 inches long) with a sticky stigmatal tip and flowers can be easily emasculated prior to anthesis. The large pollen grains are shed in tetrads which can be separated and placed on the stigmatal surface. It takes eight to nine weeks from seeding to blooming, with a prolific flowering cycle that comes in flushes. $\mathbf{N}$ umerous seeds (about 750 per capsule) are obtained in three weeks after self- or cross-pollination. The influences of three genes that control flower color and pigmentation pattern can be conveniently demonstrated with their dominant and recessive alleles. $T$ he $R$ gene controls flower color with red ( $R$ R or $R \mathbf{r}$ ) being dominant over yellow ( $r r)$. T he $D$ gene controls the density of pigmentation with solid (DD or Dd) color being dominant over dilute (dd) color. Corolla color striping is controlled by the St gene with striped (sts) being recessive to nonstriped (StSt or Sts) pattern. By using diploid lines of genotypes R R DD (red, solid), R R dd (red, dilute), or rrdd (yellow, dilute) and their crosses, students can easily observe a dominant phenotypic expression in the $F_{1}$ hybrid and the digenic 9:3:3:1 segregation ratio in the $F_{2}$ progeny. Another gene (C ) that controls flower opening can also be used to show its influence on cleistogamous (closed, selfpollinated, CC or C c) versus normal chasmogamous (open-pollinated, cc) corolla development. In addition, the induction and use of polyploid (4x) plants in plant breeding can also be demonstrated using this species.

A number of annual flowering plants can be used as demonstration materials for plant breeding classes if certain genes and their expressions are readily identifiable. R equirements for such model plants include easily recognizable genetic traits, consistency in phenotypic expression, ease of plant culture and pollination, a clear pattern of genetic segregation in the progeny, abundant seed production, and a short life cycle. O ne of the most excellent demonstration plants is the velvet flower. $\mathrm{N}$ ative to $\mathrm{Chile,} \mathrm{Salpiglossissinuata} \mathrm{is} \mathrm{a}$ member of Solanaceae, closely related to petunia, and used as an annual flowering garden plant. This plant has many desirable characteristics such as large pistils and anthers, rich corolla color variation, and numerous seeds formed from one pollination.

\footnotetext{
D epartment of Plant Sciences, N orth D akota State U niversity, Fargo, N D 58105; e-mail: chlee@badlandsnodak.edu.

Special thanks are expressed to $\mathrm{H}$ omer $\mathrm{T}$. Erickson and J ules] anick for introducing me to research topics involving sal piglossis. I would also like to thank Douglas N eedham, James Steadman, Patrick Conner, Lijuan Wang, Shanqiang Ke, and others who provided information and technical assistance. The cost of publishing this paper was defrayed in part by the payment of page $\mathrm{charges}$. U nder postal regulations, this paper therefore must be hereby marked advertisement solely to indicate this fact.
} 
T able 1. Chasmogamous breeding lines of Salpiglosis sinuata available for use in genetic studies (E rickson et al., 1982).

\begin{tabular}{llll}
\hline Line & Flower color & Ploidy & G enotype \\
\hline P-1 & Solid red & $2 x$ & ccR R D D \\
P-2 & Dilute red & $2 x$ & ccR R dd \\
P-3 & Blue stripes & $2 x$ & ccY sts \\
P-4 & Solid yellow & $2 x$ & ccr D D \\
P-5 & Dilute yellow & $2 x$ & ccrrdd \\
P-6 & Solid red & $4 x$ & ccccR R R R D D D D \\
P-7 & Dilute red & $4 x$ & cccCR R R R dddd \\
P-8 & Solid yellow & $4 x$ & ccccrrrrD D D D \\
\hline
\end{tabular}
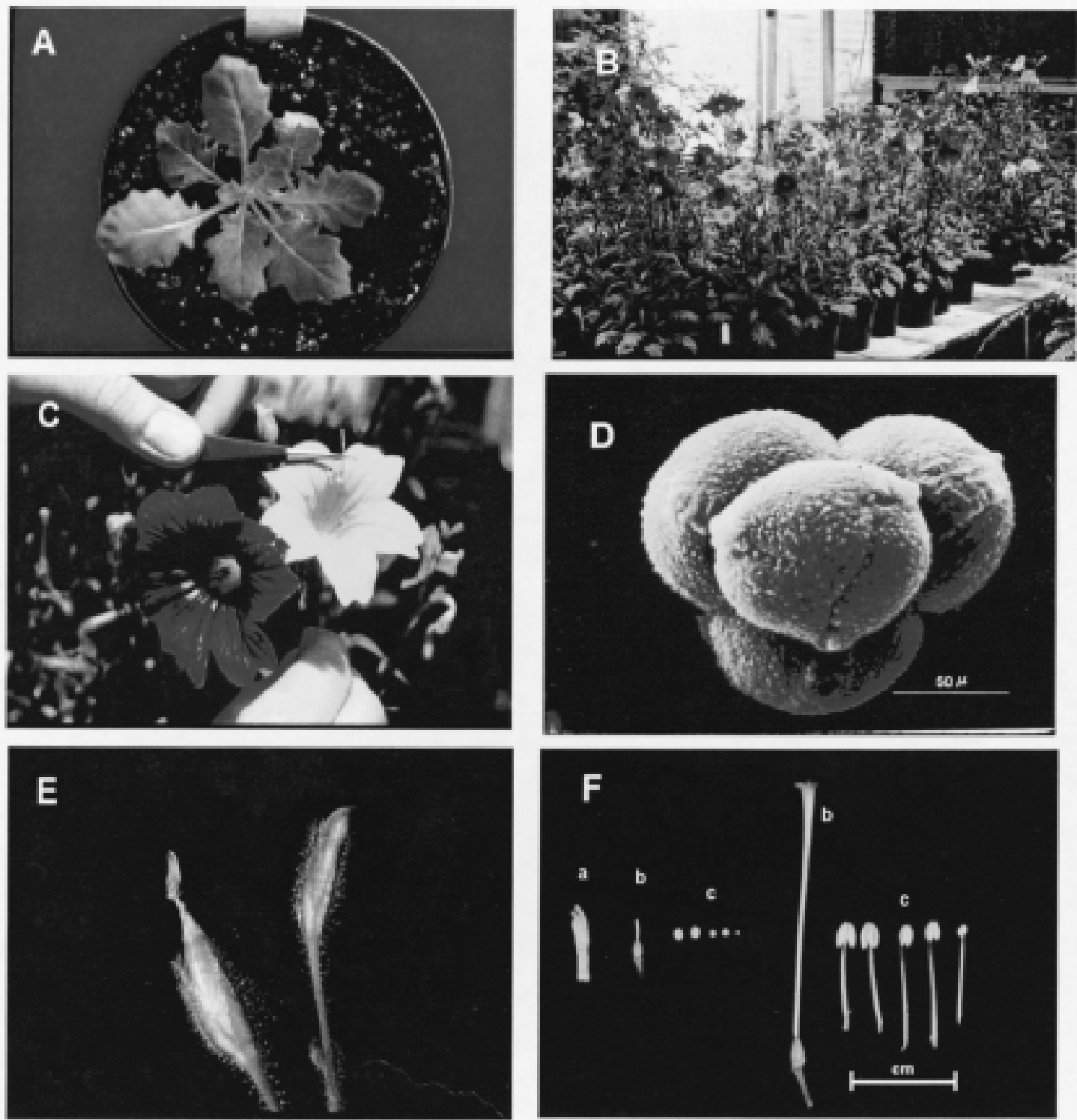

Fig. 2.

Fig. 1. G rowth and flowering in Salpiglosis sinuata: (A) a seedling plant (30 d old); (B) flowering plants (60 d old); (C) hand pollination on chasmogamous flowers; (D) four pollen grains shed as a tetrad; (E) cleistogamous flowers at pollination stage (right) and 1 week later (left); (F) reproductive parts of cleistogamous (left) and chasmogamous flowers (right) at pollination stage (a-corolla of the cleistogamous flower bud, b-pistil, c-anthers, corolla of the chasmogamous flower not shown). 

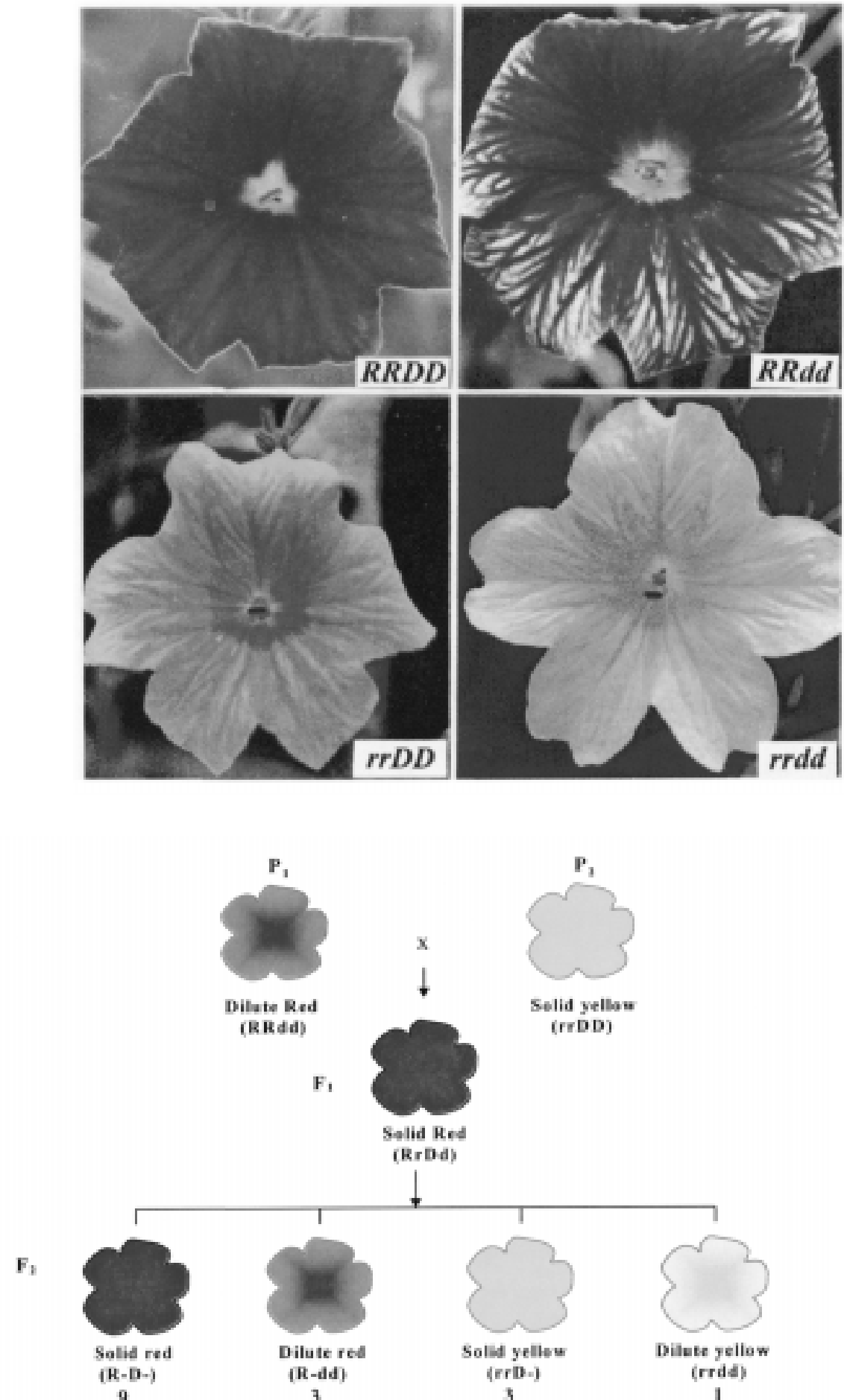

Dilate Red (RRdd)
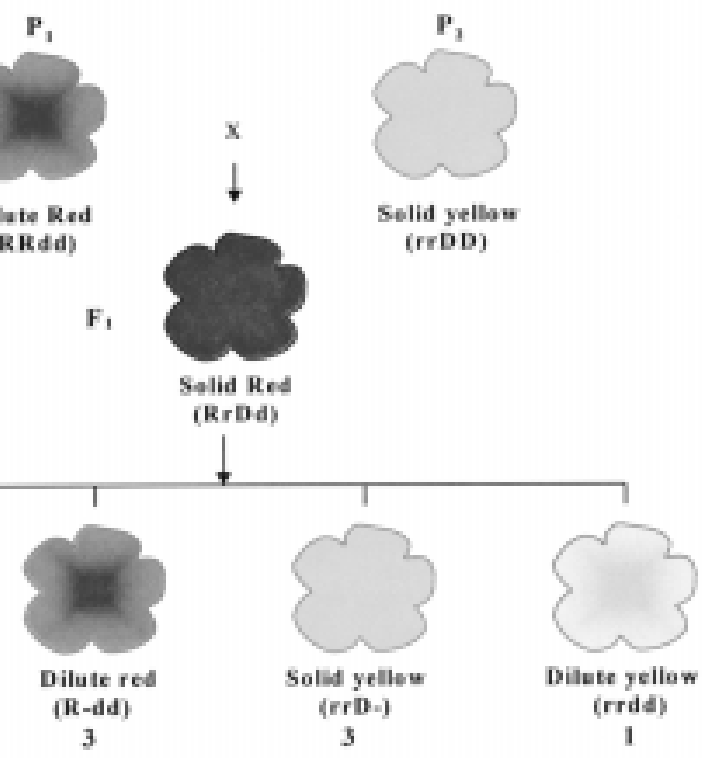

1

Fig. 4. Inheritance of flower color and color pattern in Salpiglossis sinuata controlled by two pairs of genes.

transplanted into alarger container such as5-cm (6-inch) diameter standard plastic pot. I t isrecommended that plants be individually staked with bamboo sticks to prevent lodging during the heavy blooming period. Plant height control
Fig. 2. Four different phenotypes of salpiglossis flowers that can be used in the classroom demonstration.

fusely for about one month followed by a cycle of flushes.

\section{Breeding lines}

Several inbred lines showing selected flower colors and color patterns are available. $\mathrm{H}$ omer $\mathrm{T}$. E rickson and Jules Janick at Purdue U niversity and their graduate students developed several homozygous inbred lines showing distinctive color and color pattern variation for use in genetic studies (Conner and Erickson, 1991; Erickson et al., 1982; Lee et al., 1976, N eedham and Erickson, 1992). Both homozygous diploid as well as tetraploid inbred lines that are completely chasmogamous are available (T able 1). In addition, lines that carry a dominant allele for cleistogamy $(\mathrm{C} C, \mathrm{C}$ ) are also available. Fig. 1 shows four different types of flower colors and color patterns.

\section{Classroom demonstration}

ObSERVATION ON fLORAL MORPHOLoGy. At the time of flowering, which takesabout two monthsfrom seed planting (Fig. 2B), students can observe and learn about many different structural parts of the flower and their functions. The chasmogamous flower is pentamerous and the large trumpetlike corolla is bilaterally symmetrical (Fig. 1). The calyx is five-lobed and green in color. Studentscan easily identify thestructure of gynoecium and androecium insidean open corolla (Fig. 1). The pistil is long ( 3 to $3.5 \mathrm{~cm}, 1.2$ to 1.4 inches) with a gradually flattened stigma which becomes moistened with watery exudate at the time of anthesis. Five two-lobed anthers are in three different sizes (two large, two intermediate, one small) and are borne versatilely on the long $(0.8$ to $1.5 \mathrm{~cm}, 0.3$ to 0.6 inches) filaments that are attached epipetalously to throat of the corolla. Anthers are easily removed beforeanthesis. Studentscan easily separate the structural parts of the flower individually.

Students will learn two different ing such growth regulators as chlormequat chloride (Cycocel), daminozide (B-Nine SP) and uniconazole(Sumagic) ( $N$ eedham and $\mathrm{H}$ ammer, 1990). At an early stage of growth, plants tend to become rossetted especially under short day conditions. D epending on light intensity, plants start blooming in two months and continue to flower protypes of flowers: chasmogamous (openpollinated) and cleistogamous (self-pollinated). The cleistogamous flowers of sal piglossis are tightly closed at the time of pollination which results in autogamy (Fig. 2E). D epending on thegenotype, some cleistogamous plants producechasmogamousflowersat theearly 


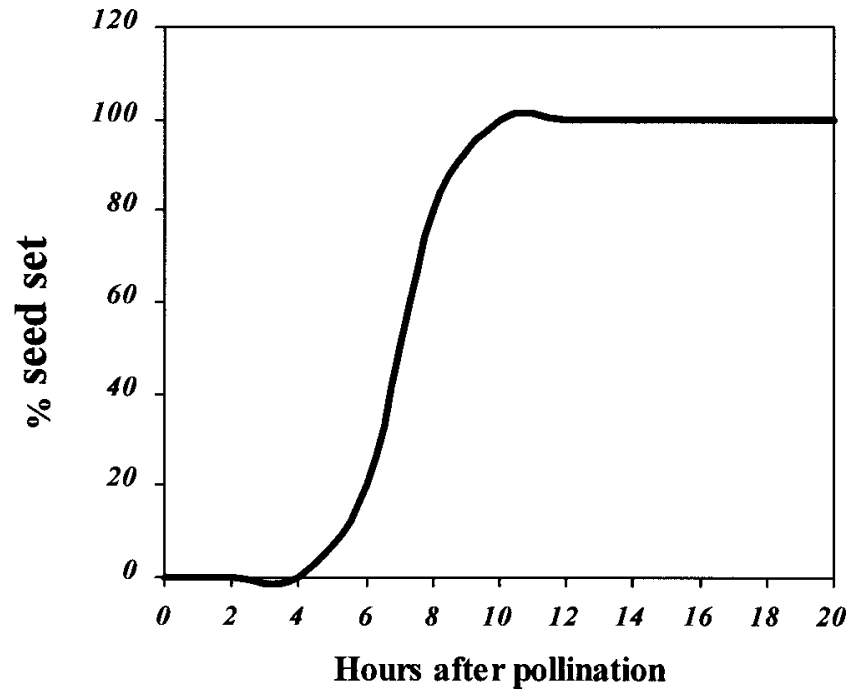

Fig. 4. Percent flowers of salpiglossis producing seed from the pistils decapitated at various time period after pollination.

T able 2. G ene symbols used for flower color and cleistogamy in Salpiglosis sinuata.

\begin{tabular}{ll}
\hline Symbol & Phenotype \\
\hline CC or C C & Cleistogamous pollination \\
CC & Chasmogamous pollination \\
R R or R r & Red flower color \\
rr & Yellow flower color \\
DD or D d & Solid flower color pattern \\
dd & Dilute flower color pattern
\end{tabular}

stage of blooming and become cleistogamouslater. Themorphology and sizes of the structural parts of cleistogamous flowers are drastically different from those of chasmogamous flowers (Fig. 3F).

Practice on pollination and fertilization. Students will use only chasmogamous flowers for pollination and fertilization studies. When the corolla begins to open, the large anthers look puffy and can easily be removed by a pair of tweezersor even fingers. Pollen grains are large (63 to $72 \mu \mathrm{m}$ in diameter) and shed in tetrads (Fig. 2D). The pollen tetrads are sticky and stay on the top surface of the open anther lobes without dispersal. When grown in the greenhouse, sal piglossis does not normally set seed mainly because of lack of insect vectors. At the time of anthesis, the large stigmatal surface is covered with viscous watery exudate that makes pollen tetradsadhere. Pollen tetradscan bepicked up with acamel hair brush and placed on the stigmatal tip during hand pollination. Students can also pick individual anthers with a pair of tweezersorfingersand directlyapplypollen on the stigma.

$U$ sing a magnifying glass or dissecting microscope, students can easily separate and pick up individual pollen tetrads on the tip of a dissecting needle and place them on the stigma. The number of seeds obtained is directly proportional to the number of pollen tetrads placed on the stigma. H owever, the minimum number of pollen tetrads that induced seed set was three (Lee et al., 1978). If pollination with one pollen tetrad results in seed set, use of salpiglossis for tetrad analysis in genetic studies may well be possible. Students may experiment to see if a large quantity of sonicated (inactivated) pollen applied to the stigma would help induce seed set from pollination with only one nonsonicated pollen tetrad.

The phenomenon of postpollination ethylene production can be demonstrated by using the pistils after pollination. Ethylene is produced as a result of interaction between the pollen tube and the stylar tissue. Pistils pollinated with increasing numbers of pollen tetrads are harvested and placed inside a sealed beaker. The amount of ethylene evolved from the pistilsinside the sealed beaker, when determined by gas chromatography, is directly proportional to amount of pollen tetrads used for pollination.

Students can determine the time needed from pollination to the completion of fertilization in salpiglossis. They can pollinate ten flowers every $2 \mathrm{~h}$ for a period of $12 \mathrm{~h}$ and then decapitate the stigmatal tips using a razor blade. Seed set from these decapitated pistils is recorded. I t usually takes 8 to $10 \mathrm{~h}$ for the pollen tubes to reach the ovules and completedoublefertilization under normal greenhouse conditions (Fig. 3). The presence of numerous pollen tubes growing through the style can also be visualized bylight microscopyafter staining the tissue in lacmoid-martius-yellow solution ( $\mathrm{N}$ ebel, 1931). Pollentubes appear blue in this stain. Ripened seeds can be harvested 3 weeks after pollina- tion. Theaverage seed set isaround 750 per capsule. Seeds stored inside a desiccation jar at $4{ }^{\circ} \mathrm{C}\left(39{ }^{\circ} \mathrm{F}\right.$ ) maintained viability for 3 years.

Demonstration ON INHERITANCE OF FLOWER COLOR. U sing inbred lines of salpiglossis(T able 1), studentscan learn about the genetics and inheritance of flower color and pigmentation pattern. Three genes that control flower color and pigmentation pattern in sal piglossis have been studied (Table 2 ). The $R$ genecontrolsflower color with red ( $R$ or $R r$ ) dominant over yellow ( $r r)$. The $D$ gene affects the corolla pigmentation pattern with solid (DD or $D d$ ) color dominant over dilute (dd) color pattern (Figs. 1 and 4). Although not discussed in thispaper, thestriping of corollacolor is controlled by the St gene with striped (sts) being recessive to nonstriped (StSt or Stst) pattern (Conner and Erickson, 1991).

At the beginning of a new semester, the instructor will provide students with seeds obtained from the previous class. If possible, obtain a complete set of seeds for two parental lines $\left(P_{1}, P_{2}\right)$, their $\operatorname{cross}\left(F_{1}\right)$, and itsselfed seed $\left(F_{2}\right)$ to makethe flower color inheritancestudy morecomprehensiveand enjoyable. For example, using the two different parental lines of R R dd (red, dilute) and rrDD (yellow, solid) and their crosses, students will be able to determine the dominance of $R$ and $D$ allelesover $r$ and $d$ in the $F_{1}$ hybrid and a digenic segregation ratio of 9:3:3:1 in the $F$ progeny (Fig. 4). The number of plants to be used to warrant the detection of homozygous recessive traits will vary with the number of genes involved. The instructor can cover the topic of minimum population size needed for $0^{2}$ test and genetic analysis for various traits being investigated.

Let students make self- and crosspollinations and harvest sufficient number of seeds to be used by each class the following year. Students can also make reciprocal backcrosses involving the $F_{1}$ and each of the parental lines for use in genetic analysis.

INHERITANCE OF CLEISTOGAMY. The $C$ gene in salpiglossis is responsible for the development of cleistogamy (closed pollination or autogamy). In contrast to chasmogamous (cc) lines, plants with CC or C C exhibit a series of altered developmental conditions that lead to cleistogamous pollination and seed set in atightly closed flower bud ( $L$ eeet al., 1978; Lee et al., 1979). In cleistoga- 
Table 3. A sample data showing the segregation of flower color and pattern and cleistogamy in the cross between two homozygous Salpiglosis sinuata lines (C C rrD D ( ccR R dd) as demonstrated by Lee et al. (1976).

\begin{tabular}{|c|c|c|c|c|c|c|c|c|c|c|c|c|}
\hline \multirow[b]{3}{*}{ Generation } & \multicolumn{4}{|c|}{ C leistogamous (C -) } & \multicolumn{4}{|c|}{ C hasmogamous (cc) } & \multirow{3}{*}{$\begin{array}{l}\text { Total } \\
\text { plants } \\
\text { (no.) }\end{array}$} & \multirow[b]{3}{*}{$\begin{array}{l}\text { Expected } \\
\text { ratio }\end{array}$} & \multirow[b]{3}{*}{$\chi^{2}$} & \multirow[b]{3}{*}{$\mathbf{P}$} \\
\hline & \multicolumn{2}{|c|}{ Red (R-) } & \multicolumn{2}{|c|}{ Yellow (rr) } & \multicolumn{2}{|c|}{ Red (R -) } & \multicolumn{2}{|c|}{ Yellow (rr) } & & & & \\
\hline & $\begin{array}{l}\text { Solid } \\
\text { (D-) }\end{array}$ & $\begin{array}{c}\text { Dilute } \\
\text { (dd) }\end{array}$ & $\begin{array}{l}\text { Solid } \\
\text { (D-) }\end{array}$ & $\begin{array}{l}\text { Dilute } \\
\text { (dd) }\end{array}$ & $\begin{array}{l}\text { Solid } \\
\text { (D-) }\end{array}$ & $\begin{array}{l}\text { Dilute } \\
\text { (dd) }\end{array}$ & $\begin{array}{l}\text { Solid } \\
\text { (D-) }\end{array}$ & $\begin{array}{l}\text { Dilute } \\
\text { (dd) }\end{array}$ & & & & \\
\hline$P_{1}$ & & & 105 & & & & & & & 105 & & \\
\hline$P_{2}^{1}$ & & & & & & & 105 & & & 105 & & \\
\hline $\mathrm{F}_{1}^{2}$ & 108 & & & & & & & & & 108 & & \\
\hline $\mathrm{F}_{2}$ & 252 & 77 & 83 & 30 & 84 & 33 & 22 & 11 & 592 & $27: 9: 9: 3: 9: 3: 3: 1$ & 3.20 & 0.87 \\
\hline $\mathrm{F}_{1}^{2} \times \mathrm{P}_{1}$ & 168 & & 159 & & & & & & & $3271: 1$ & 0.24 & 0.65 \\
\hline $\mathrm{F}_{1}^{1} \times \mathrm{P}_{2}^{1}$ & 70 & 77 & & & 70 & 78 & & & & 2951:1:1:1 & 0.75 & 0.86 \\
\hline
\end{tabular}

mous plants, massive pollen germination takes place inside the anther at the early stage of flower bed development. Pollen tubes grow out of the anther wall, penetrate the stigma and stylar tissues, and quickly complete double fertilization. Cleistogamousplantsmassively produceseedsundernormal greenhouseconditionswhere pollination vectors are not present.

Sincethecleistogamousplants(CC, Cc) also produce chasmogamous flowers at early stages of flowering, crosses between normal and cleistogamous plants have been possible. Plants possessing the $C \mathrm{C}$ genotype produce more seeds than those with the C c genotype. Theaction of the $C$ geneisindependent of any of the genes involved in flower color determination (Table 4). When cleistogamous plants with solid yellow flower color (CCrrDD) and the chasmogamous plants with dilute red flower color (ccR R dd) were crossed, the $F_{1}$ hybrid plants became cleistogamous with solid red flower color $(C \mathrm{RrDd})$. The $\mathrm{F}_{2}$ progeny showed a typical trigenic segregation ratio of 27:9:9:3:9:3:3:1 forC -R -D -:C -R - dd:CrrD-:C -rrdd:ccR -D -:ccR -dd :ccrrD :ccrrdd phenotypes (Table 3). The use of these three independent genes for classroom may betoo cumbersomesince the demonstration requiresalargenumber $(>200)$ of plants in the $F_{2}$ population to obtain statistically significant segregation data. H owever, seeds of these lines have been kept for future use and distribution. The use of the $C$ gene in the study of floral morphogenesis may well be pursued by future graduate students.

\section{Discussion}

Several well-documented genes, unique floral morphology, and a relatively short growing cycle make salpiglossis an excellent plant for use in plant breeding classes. Several breeding lines of this species have been developed to facilitate genetic studies. There are some drawbacks in growing salpiglossis in the greenhouse, mainly its vulnerability to whitefly (Trialeurodessp.) and glandular secretions that make the plants somewhat sticky. Although not discussed in this paper, salpiglossis can al so be used for demonstration in teaching plant regeneration (L eeet al., 1977) and transformation (C.W. Lee, unpublished). Instructors of general botany, introductory horticulture, and plant breeding classesmay well takethefull advantage of using salpiglossis as a demonstration plant.

\section{Literature cited}

Conner, P. and H.T. Erickson. 1991. Inheritance of corolla striping and flower colors in Salpiglossis sinuata. H ortScience 26(12):15491550.

Erickson, H.T., J. Steadman, C.W. Lee, and J. J anick. 1982. $\mathrm{P}_{1}-\mathrm{P}_{8}$, diploid and tetraploid Sal piglossis germplasm. H ortScience 17:260.

Lee, C.W., H .T. Erickson, and J. Janick. 1976. I nheritance of cleistogamy in Salpi glossissinuata. J. H ered. 67:267-270.

Lee, C.W., H.T. Erickson, and J. Janick. 1978. Chasmogamous and cleistogamous pollination in Salpiglossis sinuata. Physiol. Plant. 43:225230.

Lee, C.W., H .T. Erickson, and J. Janick. 1979. Cleistogamy in Sal pi glossissinuata. Amer. J. Bot. 66:626-632.

Lee, C.W., A.I. Soltero, R.M. Skirvin, and J. Janick. 1977. T issueculture of Salpiglossissinuata L. from leaf discs. H ortScience 12:547-549.

N ebel, B.R. 1931. Lacmoid-martius-yellow for staining pollen tubes in the style. Stain T echnol. 6:27-29.

N eedham, D.C. and H.T. Erickson. 1992. Fecundity of tetraploid ( diploid crosses and fertility of the resultant triploids in Salpiglossis sinuata. H ortScience 27:835-837.

N eedham, D.C. and P.A. H ammer. 1990. Control of Salpiglossiss nuata height with plant growth regulators. $\mathrm{H}$ ortScience 25:441-443. 